\title{
IMPLEMENTASI PEMBELAJARAN BERBASIS MULTI REPRESENTASI UNTUK PENINGKATAN PENGUASAAN KONSEP FISIKA KUANTUM
}

\author{
Abdurrahman, Liliasari, A. Rusli, dan Bruce Waldrip \\ Universitas Lampung, Sekolah Pascasarjana Universitas Pendidikan Indonesia, \\ Institut Teknologi Bandung, dan Monash University (email: abe@unila.ac.id; \\ HP. 08127911494)
}

\begin{abstract}
Implementation of Multiple-Representation-Based Instructions to Improve the Mastery of Quantum Physics Concepts. This study aimed to design and investigate the role of multiple-representation-based instructions in the improvement of student teachers' quantum physics mastery. This study used a quasi-experimental control group pretest-posttest design as quantitative part of a mixed-methods study. The subjects were student teachers of physics in the Department of Mathematics and Science Education in a state university in Lampung Province in the 2009-2010 academic year. For assessing the quantum physics mastery, the Quantum Physics Concept Achievement Test (QPCAT) was used. The quantitative analyses were conducted using the Mann Whitney $\mathrm{U}$ test. The results showed that multiple-representation-based instructions had a significant effect on student teachers' quantum physics concept mastery. The results of semi-structured interviews as qualitative part of this study indicated that in the experimental group the students used a variety of representation modes in the learning process and were capable of using the most appropriate one to solve a given quantum physics concept problem.
\end{abstract}

Keywords: quantum physics, multiple representations, concept mastery

\section{PENDAHULUAN}

Fisika adalah mata pelajaran yang memiliki catatan panjang dalam keberhasilannya menciptakan pengetahuan baru yang diaplikasikan pada berbagai pengalaman manusia dalam skala luas dan mendorong pengembangan teknologi. Fisika juga merupakan jantung perkembangan teknologi informasi dan komunikasi yang telah mengubah secara mendasar kehidupan manusia dalam dekade terakhir. Fisikawan bekerja mengawal teknologi baru, termasuk nanoteknologi yang memicu perubahan peradaban manusia secara drastis dan berkesinambungan.

Berdasarkan pandangan global dan historis, ilmu fisika telah menyediakan secara instan metode lebih generik dalam membantu manusia menganalisis dan menyelesaikan masalah kehidupan yang kompleks. Namun, fisika sebagai mata pelajaran di sekolah masih mendapatkan reputasi yang buruk, yaitu terasa sulit untuk dipelajari dan tidak diminati oleh sebagian besar siswa. Oleh karena itu, 
fisikawan atau guru, bahkan peminat fisika umumnya, mempunyai masalah sangat besar dalam upaya menyajikan pembelajaran fisika lebih bermakna dan membuat generasi muda terpesona dan tertarik untuk mempelajarinya (Euler, 2004:177)

Para pendidik fisika, baik di sekolah menegah maupun di perguruan tinggi menghadapi sebuah kenyataan bahwa fisika merupakan mata pelajaran tidak menarik dan tidak diminati, terutama dengan topik fisika modern atau fisika kuantum. Padahal, ilmu pengetahuan dan teknologi modern saat ini berkembang sebagai hasil dari pengembangan dan penelitian ilmu fisika pada topik tersebut (Zollman, Rebello, dan Hogg, 2002: 252). Fisika kuantum merupakan basis utama untuk memahami alam semesta. Namun, terkadang kebanyakan perkuliahan atau pembelajaran konsep ini berupaya untuk mengabaikannya karena siswa selama ini menganggap bahwa fisika kuantum adalah topik yang sangat mikroskopik, mempelajari hal-hal yang tidak teramati langsung oleh indera, dan membutuhkan pemahaman matematika tingkat tinggi (Hobson, 1996:202). Fisika kuantum sebenarnya dapat menjadi suatu bidang kajian yang sangat menarik bagi siswa, namun kebanyakan mereka menganggap fisika kuantum merupakan materi fisika yang sangat abstrak dan secara konseptual sulit dipahami (Asikainen, et al., 2005:1).

Berbagai studi menunjukkan bahwa guru merupakan faktor utama yang menentukan keberhasilan suatu proses pembelajaran. Namun, ternyata masih banyak guru yang penguasaan konten fisikanya belum begitu memuaskan, terutama penguasaan konsep fisika kuantum. Berdasarkan penelitian Bao dan Redish (2003:211), banyak guru-guru fisika yang penguasaan konsep fisika kuantum berada dalam level sangat rendah. Dengan demikian, membekali mahasiswa calon guru fisika dalam penguasaan konsep fisika kuantum dan bagaimanamengajarkannya merupakan hal yang sangat penting.

Telah banyak dilakukan upaya untuk mengajarkan fisika kuantum secara inovatif di universitas, seperti yang dilakukan Zollman, Rebello, dan Hogg (2002:252-259) yang telah mengembangkan pembelajaran VQM ( $V i-$ sual Quantum Mechanics) yang berusaha untuk membuat konsep fisika kuantum lebih mudah dipahami melalui visualisasi gejala kuantum. Roblee, Garik, dan Abegg (1999:11) melaporkan telah berhasil mencapai pembelajaran fisika kuantum yang cukup berhasil pada mahasiswa calon guru sekolah menengah melalui software Quantum Science Across Disciplines (QSAD).

Bagaimana dengan guru-guru fisika di tanah air kita? Berdasarkan hasil angket, observasi, dan wawancara dengan guru-guru sekolah Mitra Tim Piloting Plus Jurusan Pendidikan Fisika FPMIPA UPI (Hinduan, dkk., 2007:754), ditemukan sejumlah permasalahan pembelajaran fisika di sekolah menengah terkait dengan kompetensi guru, yaitu penguasaan materi ajar, penguasaan pedagogik, kemampuan menterjemahkan kuriku- 
lum dalam merancang pembelajaran, kemampuan melakukan asesmen, dan keterampilan berinkuiri. National Science Education Standards menyatakan bahwa calon guru fisika perlu mempelajari sains yang esensial melalui konteks dan inkuiri ilmiah. Calon guru sains harus mempelajari sains melalui inkuiri yang memberi kesempatan pada mereka untuk melakukan observasi dan bekerja dengan melibatkan penalaran dalam perumusan prinsip-prinsip (NSES, 2003:175).

Fisika sebagai sebuah mata pelajaran, dalam menguasainya dibutuhkan pemahaman dan kemampuan cara representasi yang berbeda-beda atau multi representasi untuk konsep yang sedang dipelajari. Namun, ketidakmampuan siswa menggunakan multi representasi dalam memahami konsep fisika nampaknya telah menjadi halangan batas pemahaman mereka (Gunel, Hand, dan Gunduz, 2006:1092). Dengan kata lain, kemampuan penguasaan konsep fisika sangat berkaitan dengan bagaimana menggunakan berbagai bahasa sains dalam pembelajaran fisika, seperti kata (oral dan menulis), visual (gambar, grafik, simulasi), simbol dan persamaan, gerak-gerik tubuh, bermain peran, presentasi, dan lain-lain yang akan memungkin mahasiswa mempelajari fisika melalui pengembangan kemampuan mental berpikir dengan baik. Inilah yang dinamakan pendekatan multi representasi atau multimode representasi (Waldrip, 2008:1).

Pada suatu kesempatan dalam perkuliahan Nobel, Richard Feynman, peraih hadiah Nobel Fisika menyatakan,
"Bisa saja sesuatu itu menjadi sangat sederhana jika Anda dapat menjelaskan hal tersebut secara utuh dalam berbagai cara tanpa segera menyadari bahwa Anda sedang menjelaskan hal yang serupa" (Feynman, 1965). Pernyataan Feynman sangat beralasan karena kamampuan seseorang merepresentasikan suatu objek atau fenomena dengan berbagai cara akan memudahkan orang tersebut memahami hal tersebut dengan baik. Ide ini konsisten dengan beberapa hasil studi yang dilakukan terhadap efektivitas multi representasi dalam pembelajaran fisika, yang akan memberikan peluang siswa memahami konsep fisika melalui berbagai cara yang mempengaruhi proses kognitif dalam dirinya.

Secara naluriah, manusia menyampaikan, menerima, dan menginterpretasikan maksud melalui berbagai cara penyampaian dan berbagai komunikasi, baik dalam pembicaraan, bacaan, maupun tulisan. Meskipun model linguistikyang berfokus pada oral dan teks tertulis sering dianggap sebagai kunci model komunikasi, model-model lain seperti visual, simbol, gambar tidak bergerak, animasi grafik, modelmodel fisik, isyarat dan gerakan juga mempunyai peran yang penting dalam proses belajar dan mengajar (Kress, et al., 2001:12). Siswa belajar lebih efektif ketika mereka mengolah informasi dengan berbagai macam cara. Pendekatan multi representasi untuk belajar dan mengajar menjadi sesuatu yang sangat berpotensi menghasilkan proses pembelajaran yang efektif. Melalui representasi yang 
beragam, akan menciptakan suasana pembelajaran dengan peran aktif seluruh potensi yang dimiliki mahasiswa, mengaktifkan kemampuan belajar (learning ability) mahasiswa, baik minds-on maupun hands-on sehingga pembelajaran fisika lebih bermakna. Ainsworth (1999:131) menyatakan bahwa multi representasi sangat terkait dan diperlukan untuk membangun kemampuan mengembangkan konsep dan metode ilmiah.

Schnotz dan Lowe (2003:119) membagi dua perangkat teknis untuk menghasilkan berbagai representasi, yaitu (1) semiotic atau format representasi seperti teks, gambar, dan suara; (2) sensori "mode" seperti visual dan auditori. Mayer (2003:125) menyatakan bahwa belajar menggunakan multi representasi memberikan peluang terjadinya pembentukan makna pada kerja memori sehingga siswa mengkaitkan antara kata dan gambar secara silmultan.

Format atau mode representasi yang beragam dalam pembelajaran suatu konsep tertentu memberikan peluang yang cukup baik dalam memahami konsep dan mengkomunikasikannya, serta bagaimana mereka bekerja dengan sistem dan proses suatu konsep fisika tertentu (Meltzer, 2005:463). Hasil penelitian lain menunjukan suatu kesepakatan bahwa representasi sangat penting bagi siswa dalam belajar suatu konsep tertentu. Representasi membantu siswa dalam pembentukan pengetahuan dan pemecahan masalah. Kita bisa mengatakan bahwa menggunakan berbagai representasi dengan kualitas tinggi dalam memecahkan satu masalah adalah satu kondisi cukup untuk keberhasilan proses belajar. Namun, hal itu belum merupakan suatu kondisi optimal yang diperlukan. Siswa menggunakan representasi untuk membantu mereka memahami situasi masalah serta untuk mengevaluasi hasilnya. Representasi selain verbal dalam suatu pernyataan masalah dapat mempunyai efek berbeda terhadap kinerja siswa dan pilihan mereka untuk mengunakan format representasi tertentu dalam penyelesaian masalah dan memicu format representasi lain. Dua kecenderungan dikembangkan dari berbagai penelitian terakhir ini, yaitu bagaimana siswa menggunakan berbagai representasi ketika memecahkan permasalahan dan bagaimana format representasi yang berbeda mempengaruhi kinerja siswa dalam pemecahan masalah (Rosengrant, Etkina, dan Van Heuvelen, 2007:1).

Penggunaan berbagai representasi yang baik dianggap sebagai kunci keberhasilan penguasaan konsep keilmuan tertentu. Terdapat dua motivasi yang patut dipertimbangkan dalam pembelajaran berbasis multi representasi, yaitu bagaimana siswa menggunakan berbagai representasi ketika memecahkan permasalahan dan mempelajari bagaimana cara terbaik mengajarkan pemecahan masalah menggunakan berbagai format representasi atau multi representasi.

Dua pendekatan pembelajaran berbasis multi representasi berbeda diberikan pada kelas di Universitas Colorado (CU) dan Rutgers. Perkuliahan di Rutgers dilakukan dengan pende- 
katan pembelajaran langsung secara ketat, menekankan heuristik khusus dan strategi pemecahan masalah secara spesifik. Pembelajaran dikembangkan berbasisinquiry, dosen menggunakan Learning Active Guide dalam perkuliahan dan resitasi menggunakan multi representasi. Perkuliahan di CU menggunakan suatu pendekatan yang tidak terarah, pemodelan yang baik dalam pemecahan masalah tanpa suatu strategi pembelajaran yang spesifik, sedikit sekali menggunakan multi representasi secara eksplist, baik dalam kuliah maupun tugas-tugas. Hasilnya menunjukkan bahwa penggunaan format representasi oleh mahasiswa konsisten dengan pendekatan pembelajaran yang diberikan. Hasil penelitian ini menunjukkan bahwa pendekatan instruksional atau suatu kombinasi berbagai pendekatan sangat bermanfaat untuk membantu siswa belajar menggunakan berbagai representasi untuk pemecahan masalah dan pengembangan konsep (Kohl, Rosengrant, dan Finkelstein, 2007:1-10).

Dengan demikian, terdapat peluang membelajarkan fisika kuantum dengan variasi penyajian yang memungkinkan terjadinya proses pengolahan informasi secara kognitif yang lebih beragam. Bervariasinya format representasi yang digunakan dan dibangun mahasiswa akan memperkuat pemahaman, bahkan kesulitan memahami suatu topik tertentu, termasuk fisika kuantum dapat diatasi dengan format representasi yang sesuai dengan karateristik materi dan kemampuan membangun format atau mode representasi tertentu.

\section{METODE}

Penelitian ini menggunakan pendekatan metode campuran atau mixed-method. Pengumpulan data, baik yang bersifat kualitatif dan kuantitatif dilakukan melalui suatu studi tunggal (Creswell \& Clark, 2007:5). Desain sequential embedded mixed-method digunakan dalam studi ini untuk menggali informasi secara lengkap subjek penelitian (Gambar 1).

Tahap kualitatif pertama dilakukan sebelum tahap kauntitatif melalui Focus Group Interview, sebuah metode kualitatif yang umum dilakukan untuk memperoleh informasi mendalam tentang pra-konsepsi atau konsepsi awal mengenai konsep fisika kuantum dan mode atau format representasi fisika yang selama ini paling sering digunakan mahasiswa dalam belajar fisika.

Tahap kuantitatif dilakukan metode kuasi eksperimen dengan desain Control Group Pretest-Postest. Dalam implementasinya, penelitian ini melibatkan dua kelompok sampel yang diambil secara purposif, yaitu kelompok eksperimen $(n=19)$ yang mendapatkan pembelajaran konsep-konsep fisika kuantum berbasis multi representasi (Group A) dan kelompok kontrol $(\mathrm{n}=18)$ yang mendapatkan pembelajaran dengan model direct instructions (Group B) pada mahasiswa pendidikan Fisika, Jurusan PMIPA FKIP, Universitas Lampung, kota Bandar Lampung, Propinsi Lampung. Gambar 2 menunjukkan representasi visual dari desain eksperimen dalam penelitian ini. 


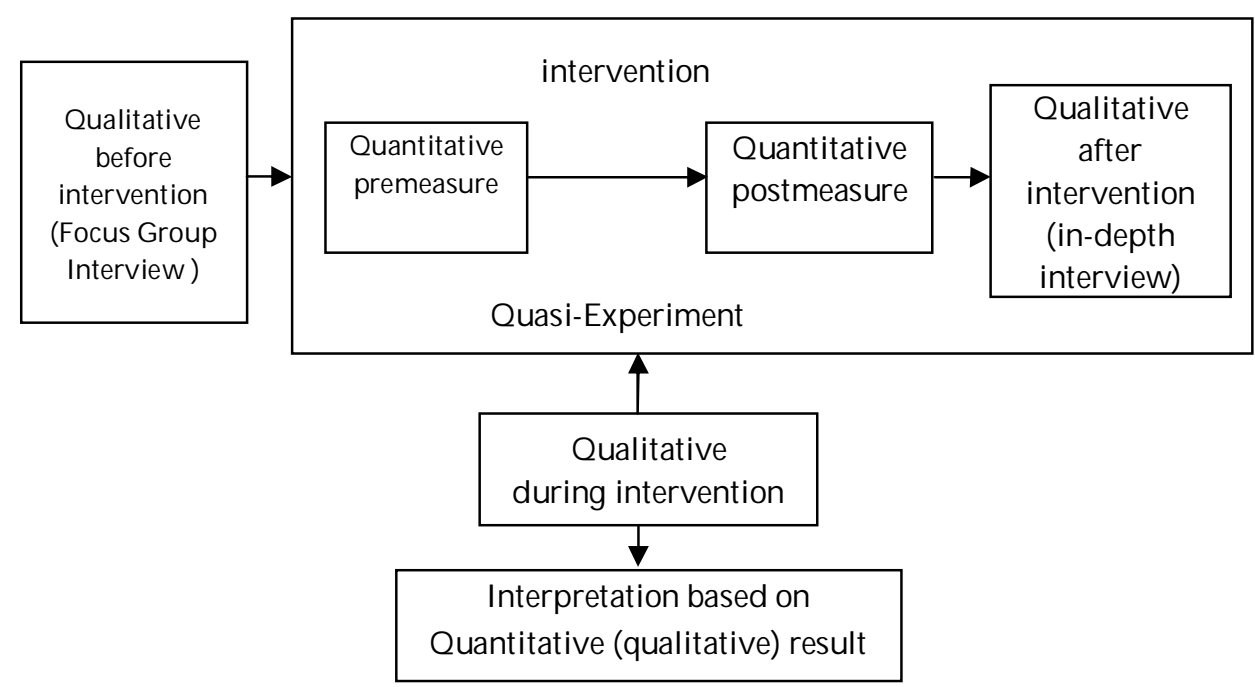

Gambar 1. Desain Sequential Embedded Mixed-Method

(Diadaptasi dari Creswell \& Clark, 2007:68)

Group $A \mathrm{O}_{1}-\mathrm{X}-\mathrm{O}_{2}$

Group B $\mathrm{O}_{1} \longrightarrow \mathrm{O}_{2}$

Keterangan :

$\mathrm{O}_{1}=$ Pre-test $; \mathrm{O}_{2}=$ Post-test $; \mathrm{X}=$ treatment

Gambar 2. Representasi Visual Desain Kuasi Eksperimen

Efektivitas pembelajaran fisika kuantum berbasis multi representasi dalam penelitian ini diungkapkan oleh perolehan gain score (N-gain) ternormalisasi tes pencapaian konsep fisika kuantum yang dihitung dengan persamaan:

$\mathrm{N}$-gain $=\frac{S_{\text {post }}-S_{\text {Pre }}}{S_{\text {maks }}-S_{\text {Pre }}}$

(Meltzer, 2002:1260)

dengan kriteria: tinggi jika $\mathrm{g} \geq 0,7$, sedang jika $0,7>\mathrm{g} \geq 0,3$, dan rendah jika $\mathrm{g}<0,3$.

Tahap kualitatif kedua dilakukan melalui semi-structure interview, sebuah metode kualitatif yang digunakan untuk mengeksplorasi pandangan dan pendapatserta proses perubahan konseptual mahasiswa secara mendalam setelah melalui pemberian perlakuan atau treatment pada tahap kuantitatif. Tahap ini melibatkan 6 orang mahasiswa yang dipilih secara acak yang mewakili kelompok prestasi atas, tengah, dan bawah.

\section{HASIL DAN PEMBAHASAN KARAKTERISTIK STRATEGI PEM- BELAJARAN BERBASIS MULTI REPRESENTASI}

Penelitian ini telah berhasil mengembangkan strategi pembelajaran matakuliah fisika kuantum berbasis multi representasi dengan pendekatan Triadic Pedagogical Model (Gambar 3) mengacu pada desain IF-SO Frame Work (Waldrip, 2008:8). 
Dalam terminologi IF-SO framework, desain pembelajaran mengikuti rancangan dan pengembangan berikut.

I:Identify key concept, yaitu mengidentifikasi konsep kunci (key concept) atau batang tubuh atau ide utama dari topik yang akan dipelajari. Hal ini sebagai landasan dalam mengkonstruksi dan mengkreasi mode atau format representasi yang digunakan guru dan siswa/mahasiswa di ruang kelas.

F: Focus on form and functions, yaitu guru atau dosen memfokuskan pada mode atau format dan fungsi representasi yang bervariasi sesuai dengan ide utama dari topik yang dipelajari. Misalnya, representasi grafik untuk menyajikan data dan menginterpretasi hasil analisis data, simulasi lepasnya elektron dari permukaan sebuah logam yang disinari oleh cahaya dengan frekuensi tertentu dalam peristiwa efek fotolistrik dapat menjelaskan peristiwa mikroskopik yang fenomenanya tidak bisa diamati secara langsung, dan lain-lain.

S: Sequence: sejumlah representasi fenomena fisis dapat disajikan atau dikreasi secara sekuensi atau berurutan sesuai dengan karakteristik atau ide utama yang menjadi pusat perhatian dan konsepsi awal siswa. Jika konsepnya abstrak, pembelajaran dapat dimulai dengan visualisasi atau simulasi konsep untuk memacu daya imaginasi dan daya tarik siswa. Siswa akan mengalami kesulitan adaptasi psikologis jika guru langsung menyajikan konsep yang sangat abstrak menggunakan persamaan matematika, karena hal ini akan menimbulkan sejumlah sikap retensi siswa berupa sulitnya belajar fisika. Sekuensi yang logis menentukan ketertarikan siswa mempelajari topik fisika dan meningkatkan persepsi positif siswa pada topik fisika yang dipelajari dan mempermudah penguasaan konsep.

O: On going assessment : Sangat penting untuk mereviu pekerjaan mahasiswa yang menggunakandanmengkreasi sendiri format representasi, guru/dosen dapat melakukan serangkaian asesmen baik formatif, diagnostik, sumatif, maupun sejumlah asesmen alternative, termasuk self- assessment sangat berguna untuk menggali alasan dan kompetensi siswa dalam merepresentasikan secara bervariasi konsep fisika yang sama.

Hubungan dan komunikasi antara guru/dosen, mahasiswa, dan domain (konsep, fenomena, ide fisis, peristiwa fisis, dan lain-lain) diperlihatkan secara visual pada Gambar 3. Komponen konsepsi guru dan kemampuan representasi guru dalam menyajikan konsep fisika harus ditopang oleh konsepsi siswa dan kemampuan menggunakan atau mengkreasi mode atau format representasi, serta akses domain yang tepat dan kaya, akan menentukan keberhasilan prosespembelajaran. 


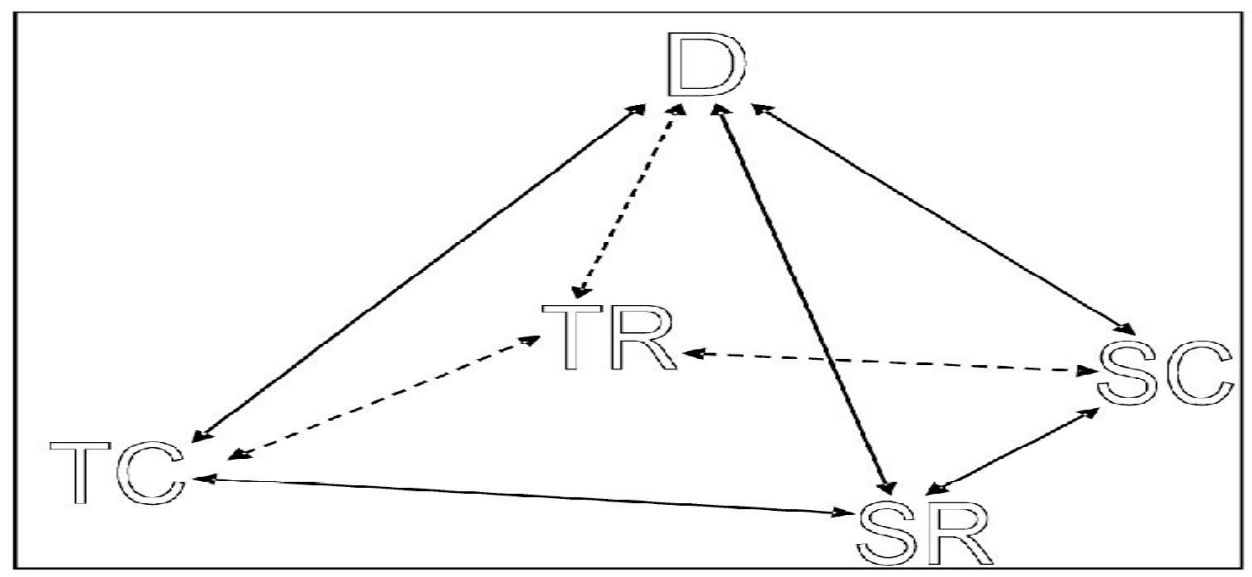

Gambar 3. Triadic Pedagogical Model dalam IF-SO Frame Work

Keterangan:

TC: Teachers' Conceptions (konsepsi guru/dosen)

SR : Students' Representations (representasi mahasiswa)

SC: Students' Conceptions (konsepsi mahasiswa)

TR: Teachers' Representations (representasi guru/dosen)

D : Domain (Fenomena fisis, konsep, gejala fisis, data fisis, objek fisis, artefak, konteks atau proses fisika dan lain-lain)

Berdasarkan model triadic pedagogi model IF-SO framework, telah dikembangkan karakteristik strategi pembelajaran berbasis multi representasi yang secara skematik dapat dilihat pada Gambar 4.

Salah satu contoh variasi mode atau format representasi untuk topik efek fotolistrik, tersaji pada Gambar 5. Guru/dosen bisa menentukan mana representasi yang harus diberikan langsung oleh siswa/mahasiswa dan mana yang dapat dibuat sendiri oleh siswa/mahasiswa (generated representtation). Pemilihan rerpresentasi di saat apersepsi, kegiatan inti, dan kegiatan akhir pembelajaran akan menentukan tercapainya tujuan pembelajaran secara optimal. 


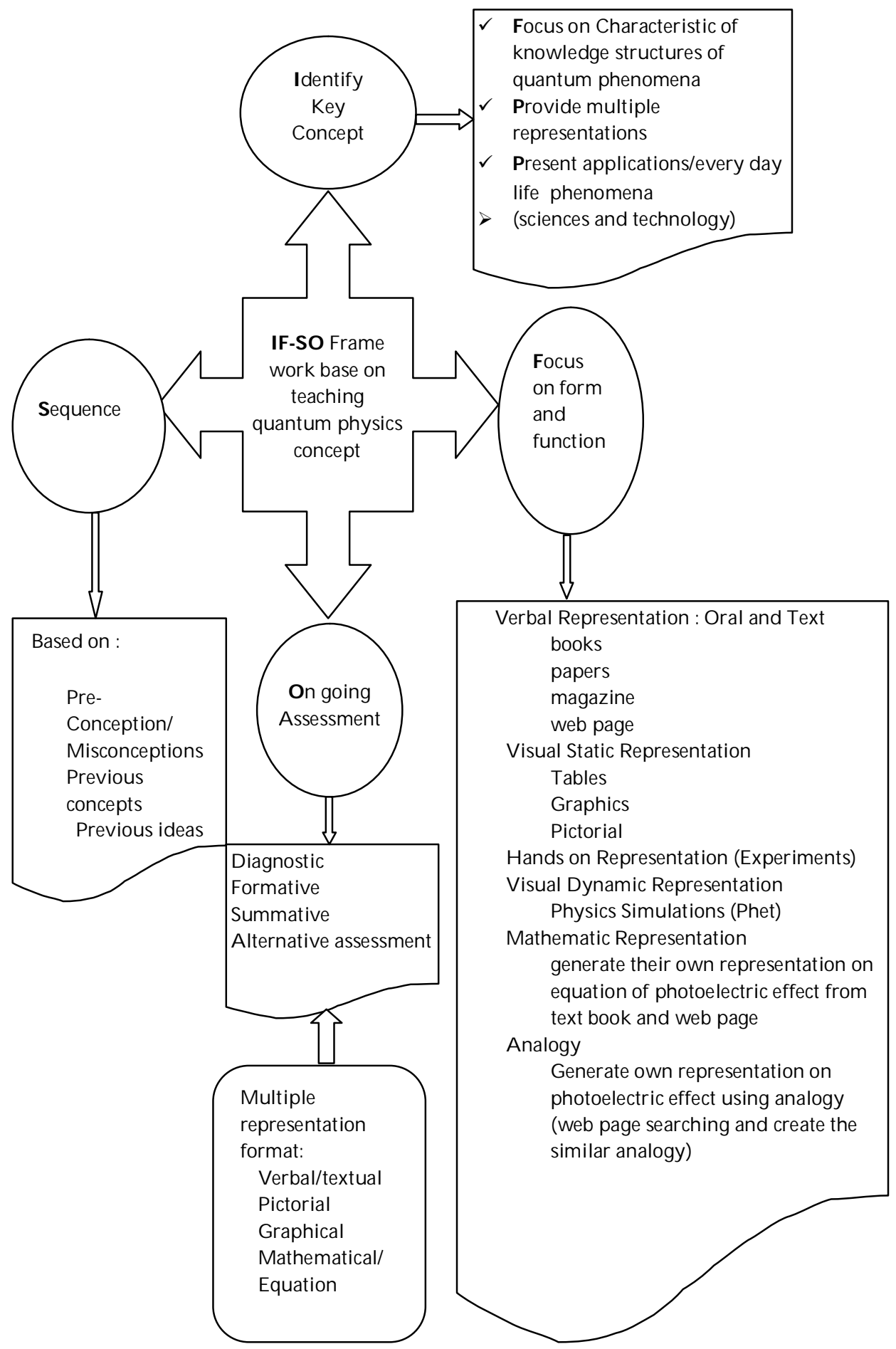

Gambar 4. Desain Strategi Pembelajaran Berdasarkan IF-SO Frame Work 


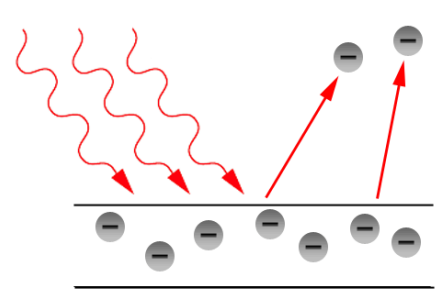

(a)

$\frac{1}{2} m v^{2}=E_{k i n}^{\max }=h v-e \phi$,

$V_{s} e=E_{k i n}^{\max }$

$\left|V_{s}^{\prime}\right|=\frac{h}{e} v-\Phi_{A}$.

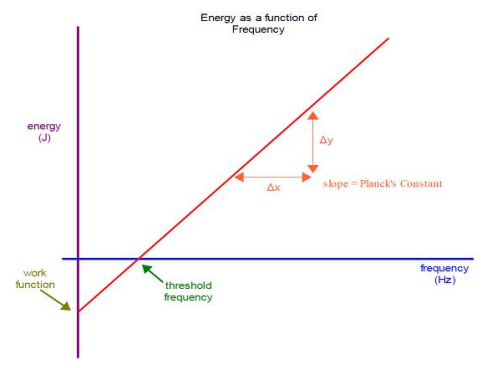

Consant ho

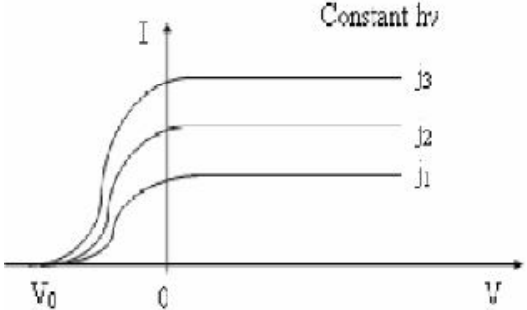

(b)

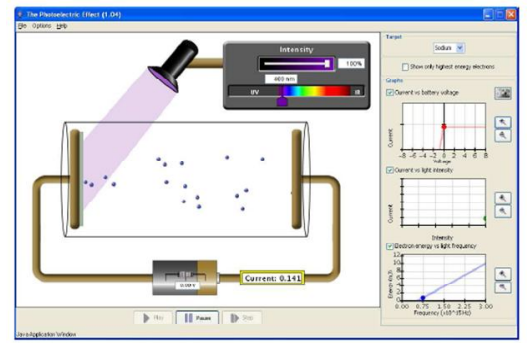

Figure 5. Multi Representasi untuk Fenomena Efek Fotolistrik (a) Gambar (b) Grafik (c) Matematika Persamaan (d) Simulasi

EFEKTIVITAS STRATEGI PEMBE-

\section{LAJARAN}

Proses pembelajaran fisika kuantum pada kelas eksperimen dalam penelitian ini telah berhasil melibatkan mahasiswa dalam berbagai pengalaman belajar yang memberikan kesempatan kepada mereka mempelajari konsep-konsep fisika kuantum melalui penyajian dan pengembangan berbagai format representasi seperti representasi verbal baik oral (melalui diskusi dan presentasi) maupun tulisan (menulis sejumlah argumentasi tentang hasil kajian konsep fisika kuantum), representasi visual baik yang bersifat statik (gambar, grafik, tabel, atau diagram) maupun yang bersifat dinamik (simulasi dan animasi gejala kuantum), representasi simbolik dan matematika, serta aktivitas laboratorium virtual.

Gambar 6 di bawah ini menunjukkan perbandingan $\mathrm{N}$-gain untuk kelas 
kontrol dan kelas eksperimen pada Bohr, dan persamaan Schrodinger. konsep efek fotolistrik, model atom

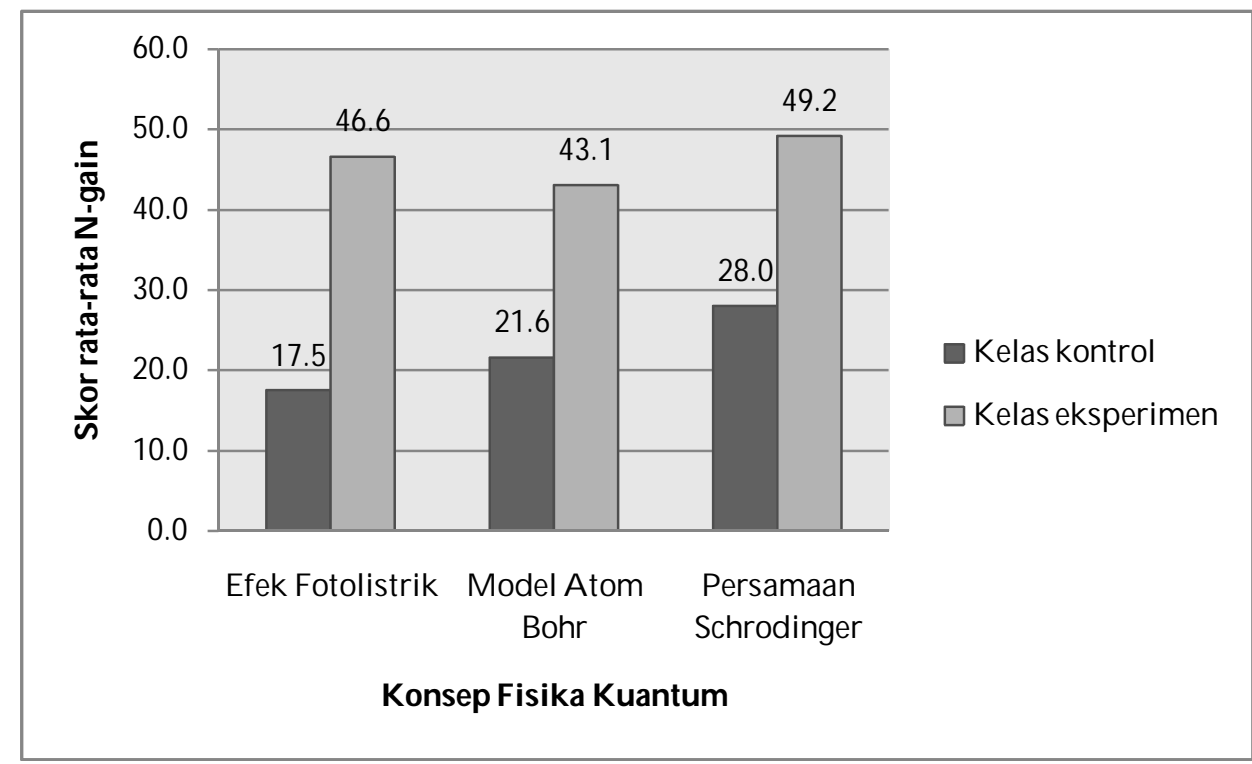

Gambar 6. Perbandingan Skor N-gain Kelas Kontrol dan Eksperimen (dalam \%)

Berdasarkan Gambar 6 N-gain kelompok kontrol untuk penguasaan konsep efek fotolistrik, model atom Bohr, dan persamaan Schrodinger berturut-turut sebesar 0,$175 ; 0,216$; dan 0,280 tergolong ketegori rendah, sedangkan skor rata-rata $\mathrm{N}$-gain pada kelompok eksperimen berturut-turut sebesar 0,466; 0,431; dan 0,492 tergolong kategori sedang.

Uji U Mann Whitney N-gain kedua kelompok topik efek fotolistrik menunjukkan perbedaan yang signifikan $(p=0.000)$. Hasil ini menunjukkan bahwa pembelajaran berbasis multipel representasi lebih efektif dalam meningkatkan penguasaan konsep efek fotolistrik mahasiswa dibandingkan dengan pembelajaran tradisional.

Tidak berbeda dengan topik efek fotolistrik, pembelajaran topik model atom Bohr berbasis multi representasi mampu meningkatkan penguasaan konsep mahasiswa calon guru fisika pada topik ini secara meyakinkan. Uji U Mann Whitney N-gain kedua kelompok menunjukkan perbedaan yang sangat signifikan $(p=0.001)$. Hasil ini menunjukkan bahwa pembelajaran fisika kuantum berbasis multi representasi efektif dapat meningkatkan penguasaan konsep mahasiswa calon guru pada topik model atom Bohr.

Khusus pada topik persamaan Schrodinger yang pada pembelajaran tradisional didominasi oleh representasi simbolik dan matematika dalam penelitian ini proses pembelajaran di kelas ekperimen, mahasiswa berinteraksi dengan mode atau format representasi yang bervariasi. Mahasiswa tidak hanya melibatkan format rep- 
resentasi simbolik dan matematik dalam pembelajaran, juga secara on-line menggunakan simulasi fisika kuantum dari http://phet.colorado.edu, sebuah web yang menyediakan berbagai simulasi dan animasi berbagai gejala fisika baik fisika klasik maupun fisika kuantum. Interaksi mahasiswa secara on-line ini mampu meningkatkan motivasi belajar mahasiswa pada topik dan konsep fisika kuantum, khususnya persamaan Schrodinger yang sebelumnya dirasakan sangat sulit dan abstrak.

Uji U Mann Whitney untuk N-gain pada topik persamaan Schrodinger menunjukkan bahwa kedua kelompok mempunyai perbedaan yang signifikan $(p=0.000)$. Hasil ini memperkuat penemuan dalam penelitian ini bahwa pembelajaran fisika kuantum berbasis multi representasi efektif dapat meningkatkan penguasaan konsep mahasiswa calon guru pada topik persamaan Schrodinger.

Keberhasilan pembelajaran berbasis multi representasi pada konsepkonsep sains dan fisika telah cukup banyak dilaporkan oleh berbagai peneliti, termasuk bagi pengembangan literasi sains (Waldrip, Prain, dan Carolan, 2006:86-105). Hasil penelitian ini juga didukung oleh beberapa penelitian sebelumnya yang menyatakan bahwa multi representasi sangat membantu siswa atau mahasiswa dalam meningkatlkan penguasaan konsep. Gunel, Hand, dan Gunduz (2006: 1092-1112) telah mengeksplorasi efektivitas representasi verbal menulis dan presentasi siswa sekolah menengah tentang konsep fisika kuantum khususnya topik efek fotolistrik dan model atom Bohr. Hasil penelitian mereka menunjukkan bahwa siswa yang menggunakan format representasi menulis presentasi berupa slide power point dan menyajikannya pada siswa lain memiliki skor rata-rata post test yang lebih baik dari kelompok siswa yang membuat format representasi verbal berupa laporan rangkuman hasil telaah terhadap konsepkonsep tersebut melalui berbagai referensi.

Dalam penelitian ini, mahasiswa calon guru fisika menggunakan dan membuat representasi bar-chart dalam menjelaskan perubahan energi kinetik, energi potensial, dan energi total sebuah elektron yang mengalami transisi dari tingkat energi tertentu ke ke keadaan dasar, misalnya membantu dalam peningkatkan penguasaan konsep model atom Bohr secara signifikan. Hasil serupa telah dilaporkan oleh Van Heuvelen dan Zou (2000: 184) dalam penelitiannya tentang konsep usaha energi pada mahasiswa fisika dasar yang melibatkan mahasiswa pada berbagai format respresentasi seperti verbal, gambar, bar-chart, dan representasi matematika, melaporkan bahwa pembelajaran berbasis multi representasi dapat meningkatkan kemampuan mahasiswa dalam menyelesaikan masalah-masalah fisika dan meningkatkan pencapaian konsep secara signifikan.

Dalam studi ini, mahasiswa calon guru telah mencoba untuk membuat sejumlah analogi dalam menjelaskan konsep terjadinya foto elektron dan tingkat energi elektron yang memban- 
tu mereka menguasai konsep-konsep fisika kuantum. Sejalan dengan hasil ini, Podolefsky dan Finkelstein (2007: 1-12) juga telah mengeksplorasi kemampuan siswa dalam membuat analogi konsep-konsep gelombang elektromagnetik (EM) sebagai bagian dari keterampilan membangun format representasi fisika dan menunjukkan bahwa analogi sebagai bagian dari format representasi dapat meningkatkan penguasaan konsep fisika siswa.

Penelitian lain yang mendukung hasil penelitian ini menyatakan bahwa format atau mode representasi yang beragam dalam pembelajaran suatu konsep tertentu memberikan peluang yang cukup baik pada pemahaman konsep dan mengkomunikasikan konsep, serta bagaimana siswa dapat bekerja dengan sistem dan proses suatu konsep fisika tertentu (Meltzer, 2005:463).

\section{HASIL INTERVIU MAHASISWA}

Pembelajaran berbasis multirepresentasi memiliki peran sentral dalam pendalaman penguasaan konsep, mengakomodasi sejumlah perbedaan latar belakang dan kecerdasan siswa, serta dapat meminimalisasi hambatan dan keterbatan siswa dalam berinteraksi dengan topik fisika yang dipelajari. Untuk mengeksplorasi sejuahmana peran pembelajaran berbasis multi representasi dalam meningkatkan penguasaan konsep, beragamnya format representasi yang digunakan dan dikreasi oleh mahasiswa, dan interaksi mereka dengan sejumlah sumber informasi konsep (domain) telah dilakukan wawancara mendalam ter- hadap 6 orang mahasiswa, yang terdiri dari 2 orang siswa dari kelompok tinggi, 2 orang dari kelompok sedang, dan 2 orang dari kelompok rendah. Secara umum hasil interviu menyajikan hal-hal sebagai berikut.

- Lingkungan belajar yang menakjubkan. Saya mulai memiliki keberanian untuk menyampaikan argumentasi dan klaim tentang topik fisika yang awalnya saya merasa tidak yakin dapat menguasainya dengan baik, percaya diri dalam problem solving. Melalui representasi yang beragam telah membuat saya jauh menjelajahi dunia mikroskopik yang luar biasa.

Representasi visual dinamik dengan simulasi komputer, membuat saya percaya diri, menguasai konsep-konsep fisika kuantum secara lebih baik. Saya bisa memastikan akan kehilangan momen terbaik mempelajari konsep fisika kuantum tanpa kehadiran simulasi yang luar biasa.

Sebelumnya saya membayangkan akan berhadapan dengan persamaan-persamaan matematika yang rumit dalam belajar fisika kuantum, ternyata melalui penjelasan verbal, gambar, grafik, dan simulasi membuat saya begitu antusias mengeluarkan daya imajinasi saya tentang dunia kuantum yang menakjubkan. Saya sangat menyukai fisika kuantum. Fisika kuantum yesss....!

Saya memang termasuk mahasiswa yang agak sulit beradaptasi dengan hal-hal baru. Sejak mulai belajar fisika, saya hanya berpikir 
bahwa format representasi yang akrab dengan saya selama ini adalah repreresentasi matematika, saya suka dengan rumus-rumus, namun terkadang sulit menangkap makna dan apa yang ada dibalik rumus-rumus tersebut. Pembelajaran fisika kuantum dengan multirepresentasi membuat saya bertambah meyakini bahwa fisika itu indah dan atraktif.

Melaluipembelajaranberbasis multirepresentasi, sebagai calon guru saya disuguhkan suatu contoh konkret bagaimana mempersiapkan, melaksanakan, dan mengakses pembelajaran fisika yang menarik dan efektif, mengaktifkan semua potensi belajar siswa, melibatkan semua sumber dan media pembelajaran, lingkungan belajar yang komunikatif, membangkitkan kreativitas, dan menyenangkan. Saya banyak memperoleh inspirasi positif, bagaimana menjadi guru yang baik.

\section{KESIMPULAN}

Dalam penelitian ini, telah dilakukan implementasi strategi pembelajaran fisika kuantum berbasis multi representasi bagi mahasiswa calon guru fisika. Melibatkan mahasiswa dengan berbagai format atau mode representasi fisis seperti verbal, visual, simbolik, matematika, dan aktivitas hands-on seperti menulis argumentasi dan presentasi, serta laboratorium virtual, telah mampu meningkatkan penguasaan konsep fisika kuantum secara signifikan. Pembelajaran fisika kuantum berbasis multipel representasi pada studi ini juga berimpilkasi pada pembekalan sejumlah pengetahuan dasar keguruan seperti Content Knowledge (CK), pedagogical content knowledge (PCK) dan pedagogical knowledge (PK) bagi mahasiswa calon guru fisika.

\section{UCAPAN TERIMA KASIH}

Peneliti mengucapkan terimakasih yang sebesar-besarnya kepada Prof. Dr. Liliasari, M.Pd atas kesempatan yang diberikan untuk bergabung dalam riset Hibah Pascasarjana SPs UPI yang didanai oleh Dikti dengan kontrak hibah : No. 2784/H40/ PL/2009. Terimakasih juga diucapkan kepada Ketua Jurusan Pendidikan MIPA FKIP Universitas Lampung atas izin dan juga mahasiswa yang terlibat dalam penelitian ini.

\section{DAFTAR PUSTAKA}

Ainsworth, S. 1999. "The Functions of Multiple Representations". Computers $\&$ Education, 33, 131-152.

Asikainen, M., Hirvonen, P. E., Heikkinen, M., Nivalainen V., \& Viiri, J. 2005. "A Novel Quantum Physics Course for Physics Teachers: Theoretical Background". Paper Presented in the Report of Cooperation Project between Universities of Joensuu and Helsinki, Helsinki.

Bao, L., \& Redish, E.F. 2003. “Understanding Probabilistic Interpretation of Physical Systems: A Prerequisite to Learning Quan- 
tum Physics". American Journal Physics, 70 (3), 210-217.

Creswell, J.W \& Clark, V.P. 2007. Designing and Conducting Mixed Methods Research. Thousand Oaks, CA: Sage.

Euler, M. 2004. "The role of Experiment in the Teaching and Learning of Physics". Proceedings of the International School of Physics "Enrico Fermi". Italia: IOS Press.

Feynman, R.1965. The Development of the Space-time View of Quantum Electrodynamics; Nobel Lecture. http://nobelprize.org/physics/a ureates/1965/feynman-lecture.html. Diunduh 19 Oktober 2009.

Gunel, M., Hand, B., \& Gunduz, S. 2006. Comparing Student Understanding of Quantum Physics When Embedding Multimodal Representations into Two Different Writing Formats: Presentation Format Versus Summary Report Format. www.interscience.wiley.com. Diunduh 15 Oktober 2007.

Hinduan, A. dkk. 2007. "Pendidikan Fisika". Dalam Ali, M., Ibrahim, R., Sukmadinata, N.S., Sudjana, D., dan Rasjidin, W (Penyunting). Ilmu dan Aplikasi Pendidikan, h 754-755, Bandung: Pedagogiana Press.
Hobson, A. 1996. "Teaching Quantum Theory in the Introductory Course". The Physics Teacher, 202-210.

Kohl, P.B., Rosengrant, D., \& Finkelstein, N.D. 2007. "Strongly and Weakly Directed Approaches to Teaching Multiple Representation Use in Physics". Physical Review Special Topiks-Physics Education Research, 3, 010108.

Kohl, B.P., \& Finkelstein, N.D. 2006. "Effect of Instructional Environment on Physics Students' Representational Skills". Physical Review Special Topiks-Physics Education Research, 2, 010102.

Kress, G., Jewitt, C., Ogborn, J., \& Tsatsarelis, C. 2001. Multimodal Teaching and Learning: The Rhetorics of the Science Classroom. London, UK: Continuum.

Mayer, R. E. 2003. "The Promise of Mulitmedia Learning: Using the Same Instructional Design Methods Across Different Media". Learning and Instruction, 13, 125- 139.

Meltzer, E.D. 2002. “The Relationship between Mathemathics Preparation and Conceptual Learning Gains in Physics: A Possible Hidden Variable in Diagnostic Pretest Score". American Journal of Physics, 70 (2), 1259-1268. 
Meltzer, D. E. 2005. "Relation between Students' Problem-Solving Performance and Representational Format". American Journal of Physics, 73 (5), 463.

NSES. 2003. National Science Education Standards : Standards for Science Teacher Preparation. Washington DC: National Academy Press.

Physics Education Technology Project. http://phet.colorado.edu, Diunduh 19 Agustus 2009.

Podolefsky, N.D, \& Finkelstein, N.D. 2007. "Analogical Scaffolding and the Learning of Abstract Ideas in Physics: An Example from Electromagnetic Waves". Physical Review Special TopiksPhysics Education Research, 3, 010109.

Robblee, K.M., Garik, P. \& Abegg, G. 1999. Using Computer Visualization to Teach Quantum Science on Pedagogical Content Knowledge. http/wwww.phys.ksu.edu/perg/ papers/narst/QM_papers.pdf, diunduh 12 Agustus 2009.

Rosengrant, D., Etkina, E., \& Van Heuvelen, A. 2007. An Overview of Recent Research on Multiple Representations. New Jersey: The State University of New Jersey.

Schnotz, W., \& Lowe, R. 2003. “External and Internal Representations in Multimedia Learning".
Learning and Instruction, 13, 117- 123 .

Van Heuvelen, A. \& Zou, X.L. 2000. "Multiple Representations of Work-Energy Processes". American Journal of Physics, 69 (2), 184.

Waldrip, B, Prain, V \& Carolan, J. 2006. “Learning Junior Secondary Science through MultiModal Representations". Electronic Journal of Science Education, 11 (1), 86-105.

Waldrip, B. 2008. Improving learning through use of representations in science. Proceeding The $2^{\text {nd }}$ International Seminar on Science Education. Science Education Program. Bandung: Graduate School Indonesia University of Education.

Waldrip, B., Prain, V., \& Carolan, J. 2010. “Using Multi-Modal Representations to Improve Learning in Junior Secondary Science". Res. Science Education, 40, 65-80.

Zollman, D. A., Rebello, N. S. \& Hogg, K. 2002. "Quantum Mechanics for Everyone: Hands-on Activities Integrated with Technology". American Journal of Physics, 70 (3), 252-259. 